permanent velue to grouse management, which is an important feature of moorland economics.

State Aid for Museums and Art Galleries of Britain

Fon many years the Museums Association, through a succession of presidents and other officials, has emphasized the desirability-indeed the absolute necessity-of giving some measure of financial assistance to museums and art galleries, especially to the smaller provincial institutions. On February 26, Sir Edward Boyle, Financial Secretary to the Treasury, made a statement in the House of Commons which indicates that H.M. Government is at last fully alive to the present needs of museums and art galleries. There was a practical result in that various grants were announced. First was the direct provision in the Estimates for the national collections, which is to show an increase of $£ 350,000$ or 13 per cent. This welcome news will allow the British Musoum to appoint fifty extra staff and enable the authorities to keep the Reading Room open to a later hour on, say, two evenings a week. Until 1959 the Victoria and Albert Museum, by means of its Circulation Department, was enabled through a Treasury Grant to disperse the hopelessly inadequate amount of $£ 2,000$ per annum to local museums for the purchase of specimens. Last year this sum was increased to $£ 15,000$, and now it is announced that the amount has been raised to $£ 25,000$. From the professional point of view, it was especially welcome news that the Minister of Education has decided to ask Parliament to approve of an entirely now type of grant to the Victoria and Albert Museum for the benefit of a provincial gallery. By this means it will be possible for Liverpool to purchase the "Holy Family" by Rubens.

It has been continually urged by the Government that the museum problem should be settled locally, and to this end the South Western Museum Regional Council was formed in January 1959. Its aim was to promote closer co-operation between museums, to improve the technical facilities available and to distribute financial assistance to museums and art galleries within the region. It was hoped that the Finaneial Secretary would be able to make a definite staternent regarding assistance to this regional scheme, especially in view of the strong support given only the day before in a memorandum by the Association of Municipal Corporations. Unfortunately he was not able to announce any grant in this connexion. But perhaps the most welcome result of the debate in the House was the statement that the Government now realizes that many museums and art galleries in Britain are inadequately provided for, and that a general inquiry would serve a useful purpose. To this end the Chancellor of the Exchequer has invited the Standing Commission on Museums and Art Galleries to consult the Museums Association and others to consider the desirability of a complete review of provincial museums and art galleries. It is to be hoped that this review will take place in the foreseeable future.

\section{Employment of Scientists in the United States}

A REPORT issued by the National Science Foundation gives final information on about 116,000 employed scientists (out of about 127,000) in the National Register of Scientifie and Technical Personnel for 1954-55, roughly half of all American seientists at the time (American Science Manpower: Employment and Other Characteristics, 1954-55. Pp. vi +48.
(N.S.F. 59-39.) Washington, D.C.: National Science Foundation, 1959). The largest group $(41,000)$ was employed in chemistry and chemical engineering. About half of the 116,000 were employed in private industry and nearly one third by educational institutions. About 50,000 (44 per cent) were engaged in research, development or field exploration, about 20,000 in management or administration and about the same number in teaching. Nearly 40 per cent of the scientists held a doctorate and more than 33 per cent a master's degree. In 1954-55 the median annual salary for scientists reporting this item was 6,525 dollars and, in general, salaries were highest for scientists with a doctorate and those employed in private industry. About 8,000 (about 7 per cent) of the scientists were women, who were employed chiefly in the biological sciences, chemistry and psychology. Of the 127,000 respondents in the 195455 Register, more than 90 per cent were civilian scientists employed in scientific or in non-scientific specialities, including education, social work, and humanities. Of the remainder, about 4,000 were on active military duty, 4,200 students, 700 unemployed and 2,000 retired. These groups are not eovered in the report.

\section{U.K. Government Relief for Scientific Societies}

ThE annual report for 1959 of the Parliamentary and Scientific Committee, besides a concise summary of the addresses and discussions during the year, records that the Committee's Rating Sub-Committee welcomed the recommendations of the Pritchard Committee insofar as they offer a 50 per cent rate relief to scientific societies and similar bodies, and extends to industrial research associations the same degree of rating relief as applies to industry in general (pp. 28. London : Parliamentary and Scientific Committee, 1960). Subject to certain reservations, the Committee hopes that the necessary legislation will be introduced by the Government at the earliest possible opportunity. First, the Committes regrets that the Pritchard Committee's recommendations, if implemented, will impose a material rate burden on those scientific organizations which have obtained total exemption under the Scientific Societies Act, 1843 , and will also debar from such full relief other scientific societies which might have been able to qualify for exemption under that Act at some future date. The Committee recommended accordingly that if the Government did not find it possible to enable scientific societies to continue to enjoy full rating relief, arrangements should be made by the Minister for Science to afford assistance to scientific societies which will be rendered less effective by the implementation of the Pritchard Committee recommendations. Secondly, the Committee submits that certain modifications in the precise recommendations of the Pritchard Committee will be necessary to ensure that some scientific societies are not debarred from the rating relief recommended by reason of the definition of what is to constitute a charity for the purpose of rating benefit.

\section{Vegetable Research}

THE Research Station at Wellesbourne, with its sub.station at Paglesham, Essex, was established in 1949 and has now a considerable volume of results (Ninth Annual Report, 1958, of the National Vege. table Research Station, Wellesbourne, Warwick. Pp. 55. 1959). A long-term assessment of chomical, physical, biological and ecological changes involved 